\title{
Siitä kulki Väinämöinen / kulki kuusissa hakona / petäjässä päänä pölkyn
}

\author{
Ready, Jonathan. 2018. The Homeric Simile in Comparative Perspective: Oral \\ Traditions from Saudi Arabia to Indonesia. Oxford: Oxford University Press. xv + \\ 315 pages.
}

Frog

$\mathrm{H}$ omeric verse has been at the center of comparative discussions of poetry for centuries. This enduring position has been maintained by Homeric poetry's role in establishing the foundation of Oral-Formulaic Theory (OFT), where it has continued to be a mooring point of discussion as OFT has gradually assimilated and superseded alternative approaches to how oral poetry works in performance. Jonathan Ready has been building a reputation for insightful and thorough work on Homeric poetry and the oral versification it reflects through extensive comparison with more recent traditions. With The Homeric Simile in Comparative Perspective: Oral Traditions from Saudi Arabia to Indonesia, Jonathan Ready launches a new strand of comparative poetics that complements and extends OFT through exploration of the rhetorical device of the simile. There are a number of such strands of comparative research parallel and complementary to OFT's formulaic language and themes as units of content. These include studies of parallelism, rhyme, alliteration and of course metrics and various performance techniques. A difference, however, is that most such broad comparative studies have been of formal constituents or structuring devices of verbal art. A comparative study of simile focuses on a type of rhetorical figure, a type of comparative study that is far more rare and also more intriguing to observe as such a wide-spread phenomenon in poetries of the world. Building on an earlier article, Ready takes on the challenging task of this broad cross-cultural investigation as a platform for contextualizing and exploring simile in Homeric poetry.

\section{Comparing Six Traditions}

The work is organized in two broad parts with an introduction and conclusion. The first part is a comparative study of the simile in five poetry traditions documented in recent centuries: South Slavic epic, which has become well known through Oral-Formulaic Theory, Kyrgyz epic of Central Asia, South Sumatran epic of Indonesia, Rajasthani epic of India, and poetry of Bedouin tribes of the Najd desert. The second part surveys similes in Homeric poetry and discusses them in relation to the other traditions. Ready anticipates that the first part of this work will be of greatest interest to folklorists working with oral poetry while the latter will 
be of greater interest to scholars of Homeric poetry, but my own response as a folklorist was in fact the reverse.

The first part of the work is organized in three chapters and raises a number of very important issues concerning the operation of poetry and poetics on an almost global scale. The six languages of traditions brought into focus in this study represent a number of different language families, with the consequence that no one scholar has mastered them all. This diversity presents the methodological issue that Ready must rely on translations for the majority of his empirical data. Generally speaking, this issue is addressed by working with dual language sources and developing the comparative study with reference to original language texts. Some comment would have been nice concerning whether the approach met with cases where the translation presents a simile but the original text does not, or whether particular languages presented issues for interpretation. In Finno-Karelian epic, for example, the verses Siitä kulki Väinämöinen / kulki kuusissa hakona / petäjässä päänä pölkyn create a relation with the essive case, which would usually be translated 'as': 'Then drifted Väinämöinen / as a log among spruces / as the end of a stump in a pine'. The translation might be interpreted as a simile, yet the essive case would usually mean 'in the state or act of being', like when someone works opettajana 'as a teacher', in which case it would not be a simile per se. Then again, the use of the essive case in these verses can also be seen as a metrically motivated alternative to $k u(i) n$ 'as, like', allowing it to be considered a simile. However, entering into such detailed operation of simile for so many poetries might have extended the work unduly.

The first chapter briefly introduces similies and discusses formal points of comparison of similes in the different poetries with Homeric similes in terms of length, duration, arrangement and position. In the short sections on each of these four points, length refers to the length of a single simile while duration is used to describe text sequences that may be prolonged through parallelism like kulki kuusissa hakona / petäjässä päänä pölkyn 'as a log among spruces / as the end of a stump in a pine'. Arrangement is presented as concerning clustering, connected with Ready's very interesting observation that similes tend to form clusters in pairs or series. The interest of this topic leads the section to be expansive, with illustrations from the different poetries discussed. Position concerns whether the simile precedes or follows that to which it is being compared.

The second chapter focuses on what Ready describes as the "spectrum of distribution". This is the chapter that reviews a number of points about oral and performative culture. The "spectrum" is one of distribution through a tradition area on the three-fold division of pan-traditional, dialectal and idiolectal (e.g. 29-30). A methodological criticism here is the inclination to infer that similes repeated within a poem are socially shared, and thus dialectal or pan-traditional, although Ready acknowledges problems with this inference (e.g. 135-136). A criticism that may be terminological rather than methodological is that otherwise unique similes are treated as idiolectal (e.g. 29, 163). Idiolect normally refers to a single individual's uniquely (if only by fractions) varied internalized understanding of a traditional idiom. Referring to expressions or features of expressions as idiolectal thus normally refers to phraseology or structures that are established parts of that person's idiolect although varying, perhaps subtly, from a collective tradition. Consequently, idiolectal expressions are normally identified as such through recurrence within and across performances by one individual while not being observed in others' performances. In this work, idiolectal is also used 
inclusively of similes that are uniquely attested in a single performance where they conform to the poetry's formal conventions. Idiolect thus seems to include both elements and features established in only one performer's understanding of the idiom and also unique expressions produced by the same performer, although some of these might be situationally motivated, accidental, experimental, or just reflect a tendency of the performer's style to produce innovative expressions. However, this use of idiolectal is something to which a reader can adjust. What may be the most significant and substantial contribution of the work is also presented here in the discussion relating use of simile to performer competence (120-126).

The third chapter then reviews similes in the five poetries being brought forward for comparison with those in Homeric verse.

The second part of the book brings Homeric poetry into focus, and here is where the work is strongest. As interesting and exciting as the topic is, discussion in the first part is oriented towards Homeric scholars, as the title of the volume suggests, and the organization of the book is to return comparative perspectives to a more focused discussion on Homeric poetry. The second part provides a more nuanced and sophisticated discussion that brings out the operation of simile in the poetry in greater detail.

\section{Style and Accessibility}

Following Ready's customary style, the study quotes extensively from a broad range of scholarship on each tradition and on the different aspects of the operation of oral traditions that enter comparative discussion. The wealth of quotations and range of works mentioned makes this book a valuable resource for other researchers, allowing them to benefit from Ready's broad reading. On the other hand, this style has a consequence that the author's own views are sometimes difficult to disentangle from those of other scholars mentioned. I suspect the author is so immersed in the literature and the material of his study that he has difficulty relating to the perspectives of outside readers. This impression arises from examples often being presented as speaking for themselves and from the thread of argument in particular sections becoming challenging to follow through a cascade of quotations, sometimes with the point of the particular section seeming to remain implicit. The book contains valuable points and discussions, but it also requires a lot of work of the reader.

This style impacts the introduction of terminology. The section "A Definition of a Simile" (0.5), for example, introduces the terms tenor for that to which comparison is being made and vehicle for that to which it is being compared. Rather than definitions proper, the reader is presented with illustrations, which start off specifying the nouns (or pronouns) being compared within a simile as the tenor and vehicle, respectively, while later on the terms seem to be used for more complex units being compared. The approach comes from I. A. Richards model for metaphor from the first half of the twentieth century and I suspect is not generally known, so clear and straightforward definitions would be decidedly helpful when the terms are not intuitive. Similarly, I found it difficult on a first reading to pin down the distinction being made between length and duration of similes in the introduction, because this seemed to rely less on explication than on an illustrative example. These sorts of issues seem to reflect the author's immersion in the subject and its vocabulary. The same is presumably also why there is no mention of the distinction between simile and metaphor. The lack of mention of 
metaphor does not significantly impact on the study, which keeps Homeric simile in focus, but it was particularly striking as an area that might be especially relevant when working with translations of poetry from diverse languages. Similarly, definition through illustration does not compromise the value of this volume's contribution, although it impacts on the ease with which a reader can extract the information it has to offer.

\section{A Perspective}

The Homeric Simile in Comparative Perspective offers precisely what the title promises. This study makes a very important move in opening such a widely used rhetorical device as simile to broad comparative discussion, as has been so long established for formulaic language, parallelism and other formal poetic devices. The strongest part of the study is the survey and discussion of simile in Homeric poetry. For the reader interested in poetic and rhetorical devices, the book includes valuable observations on the clustering of simile in the types of poetry reviewed, which will hopefully stimulate further comparative discussion. A significant contribution of this work is in consideration of use of simile as a potential relevant indicator of performer competence, which will also be interesting to have discussed in relation to additional traditions and empirical data.

Frog is an Academy of Finland Research Fellow of Folklore Studies, University of Helsinki, with the project "Mythology, Verbal Art and Authority in Social Impact" (2016-2021). 